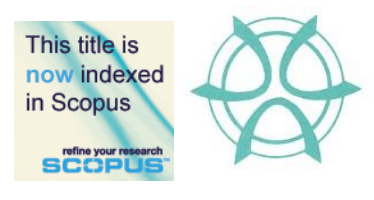

PLANNING MALAYSIA:

Journal of the Malaysian Institute of Planners

VOLUME 16 ISSUE 4 (2018), Page 143 - 154

\title{
VISITORS PERSPECTIVES TOWARDS THE CONSERVATION OF HERITAGE BUILDING: THE CASE STUDY OF GURNEY PARAGON MALL, PENANG
}

\author{
Normah Abdul Latip ${ }^{1}$, Norazmawati Md Sani@Abd Rahim ${ }^{2}$, Syarmila Hany \\ Haron $^{3}$, Rosniza Hamzah ${ }^{4}$, Adaweia Nuur Abu Bakar ${ }^{5}$, \& Mohd Umzarulazijo \\ Umar $^{6}$ \\ ${ }^{1,2,3,5,6}$ School of Housing Building and Planning \\ UNIVERSITI SAINS MALAYSIA \\ ${ }^{4}$ Faculty of Engineering Technology \\ UNIVERSITI MALAYSIA PERLIS
}

\begin{abstract}
The purpose of this paper is to acquire a better understanding of the history, background, process and impact of the restoration of St. Joseph's Novitiate, and it integration into Gurney Paragon Mall. St. Joseph's Novitiate has significant historical, architectural, aesthetic, archaeological, spiritual, social, political and economic value, and as such, requires continuous care and preservation. This study explores the perspectives of visitors to the shopping mall, with St. Joseph's Novitiate having been physically integrated into the mall's construction, and found that the conservation of heritage buildings was regarded as very important, even when a new development could easily replace the historic building. This is likely a one of a kind study because it involves a modern shopping mall attached to a UNESCO World Heritage Site building. The conservation of historical buildings carries with it a number of environmental, social and cultural impacts. Understanding these impacts is important in terms of trying to determine whether conservation efforts help to maintain the value of the heritage.
\end{abstract}

Keywords: visitor perspective, heritage building, shopping mall 
Normah Abdul Latip, Norazmawati Md Sani@Abd Rahim, Syarmila Hany Haron, Rosniza Hamzah, Adaweia Nuur Abu

Bakar, \& Mohd Umzarulazijo Umar

Visitors Perspectives Towards the Conservation of Heritage Building: The Case Study of Gurney Paragon Mall, Penang

\section{INTRODUCTION}

The conservation of heritage buildings is a vital component of urban revitalization. Conservation both maintains and increases the value of buildings by keeping their original built form and architectural elements intact. This includes the process of building restoration and not simply the replacement of the existing building. Notwithstanding, there is still a lack of understanding among the general population as what heritage conservation entails. Similarly, there appears to be confusion among many municipal councils as to meaning of conservation and its integral role in development, a concept which is advocated by the conservation lobby (Jenkins \& King, 2003). Without the proper supervision and maintenance of historic buildings, a nation will eventually lose its historic townscapes, which are in many ways what makes a city unique. Moreover, preservation plays an important role in world recognition (Ahmad, 2006), as in the cases of George Town and Melaka, two historic Malaysian cities that were recognised as UNESCO World Heritage Sites in July 2008.

Heritage building conservation of is not only important to make the building useable, but also preserves the uniqueness of the heritage building from the passage of time. Nonetheless, heritage buildings will inevitably deteriorate over time (Azmin, Kassim, Abdullah, \& Sanusi, 2017) thus reducing the quality of the building structure, services and maintenance. Systematic and routine maintenance works are often neglected parts of conservation programmes, largely because there is a misunderstanding as to the need for such works subsequent to restoration work (Abdul Rashid \& Ahmad, 2011). Above all, it is imperative that efforts be undertaken to improve stakeholder and public knowledge with respect to heritage conservation (Zawawi \& Abdullah, 2011).

\section{RESEARCH BACKGROUND}

Gurney Paragon Mall is located on Penang Island on the northwest coast of Peninsular Malaysia. Penang is a state divided into two geographic divisions: Penang Island, home to the state capital, George Town; and Seberang Perai on the Peninsular Malaysia mainland. Penang is a highly urbanised and developed state, and also home to one of Malaysia's most thriving tourist industries. Penang's population numbers 1.74 million (Department of Statistics Malaysia, 2018), representing a diversity of cultures (Lee, Lim, \& Nor'Aini, 2008), ethnicities (Leng, Badarulzaman, Samat, Rohayah, \& Dawood, 2014), languages and religions. This diversity can be seen throughout the whole year with many festivals being celebrated, some festivities welcoming the patronage of different races and sometimes even tourists. Moreover, George Town is one of Malaysia's oldest continually inhabited cities. George Town was founded by Sir Francis Light, who was a ship captain and trader for the British East India Company, after being instructed to do so by the company, Jourdan Sullivan and de Souza, to establish a presence in the Malay Archipelago. Sir Francis Light would eventually 
PLANNING MALAYSIA

Journal of the Malaysia Institute of Planners (2018)

go on to negotiate a treaty with the Sultan of Kedah for control over Penang Island. Fort Cornwallis (Harun, Ahmad \& Badarulzaman, 2004) was subsequently established on the northeast of the island, after which Sir Francis Light instituted a number of policies aimed at successfully increasing the value of imports to the island and raising the population of the settlement. These strategic objectives were largely satisfied with the implementation of a free trade policy, popular among British colonies at the time.

Gurney Paragon Mall, also located on the northeast of Penang Island (Figure 1) with a shopping complex that incorporates St. Joseph's Novitiate as the focal point of the mall (Figure 2). The novitiate building has two courtyard either side, making it perfect for al fresco dining. Moreover, Gurney Paragon Mall is home to more than 40 fashion boutiques and 30 restaurants. The mixed development comprises the nine-storey mall, luxury residences and office towers.

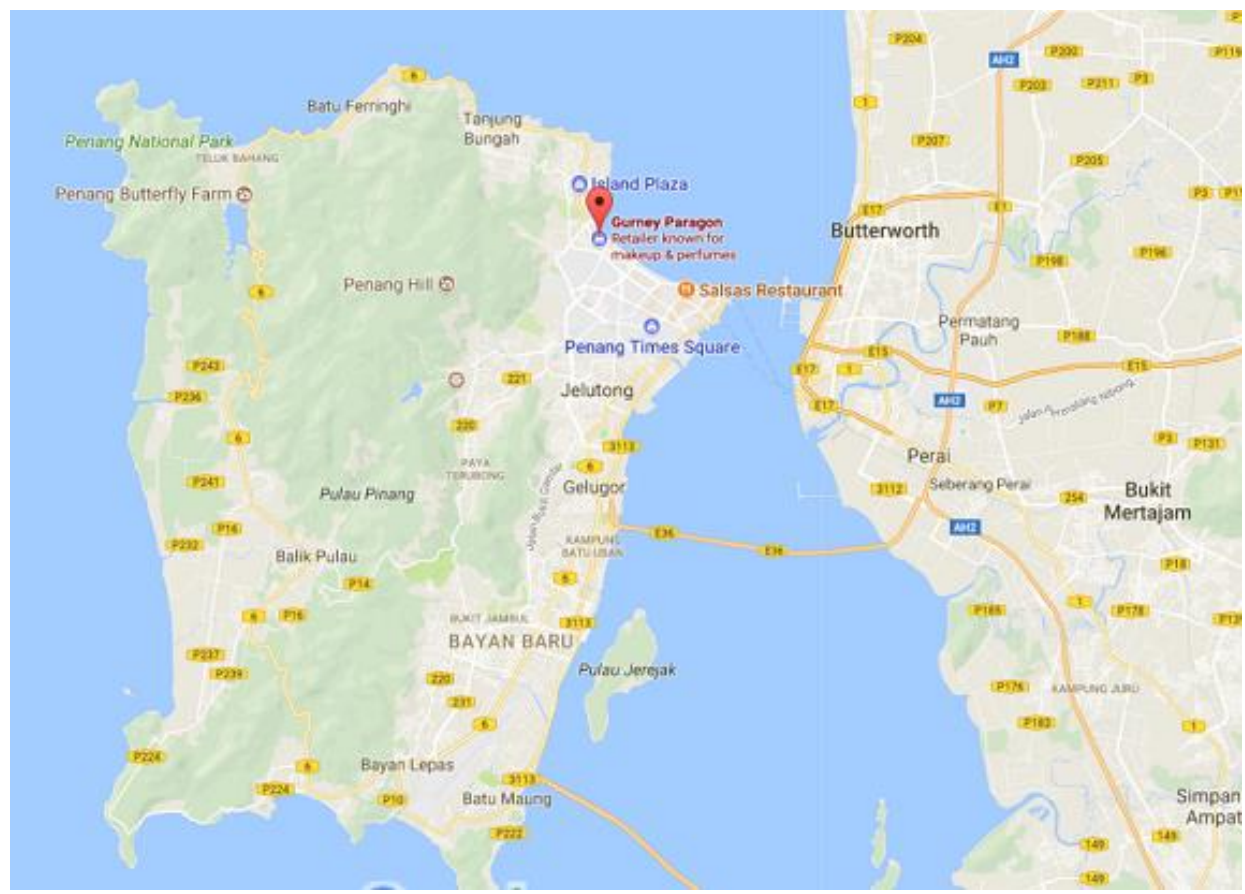

Figure 1: Location map of Gurney Paragon Mall Source: www.gurneyparagon.com, 2017 
Normah Abdul Latip, Norazmawati Md Sani@Abd Rahim, Syarmila Hany Haron, Rosniza Hamzah, Adaweia Nuur Abu Bakar, \& Mohd Umzarulazijo Umar

Visitors Perspectives Towards the Conservation of Heritage Building: The Case Study of Gurney Paragon Mall, Penang

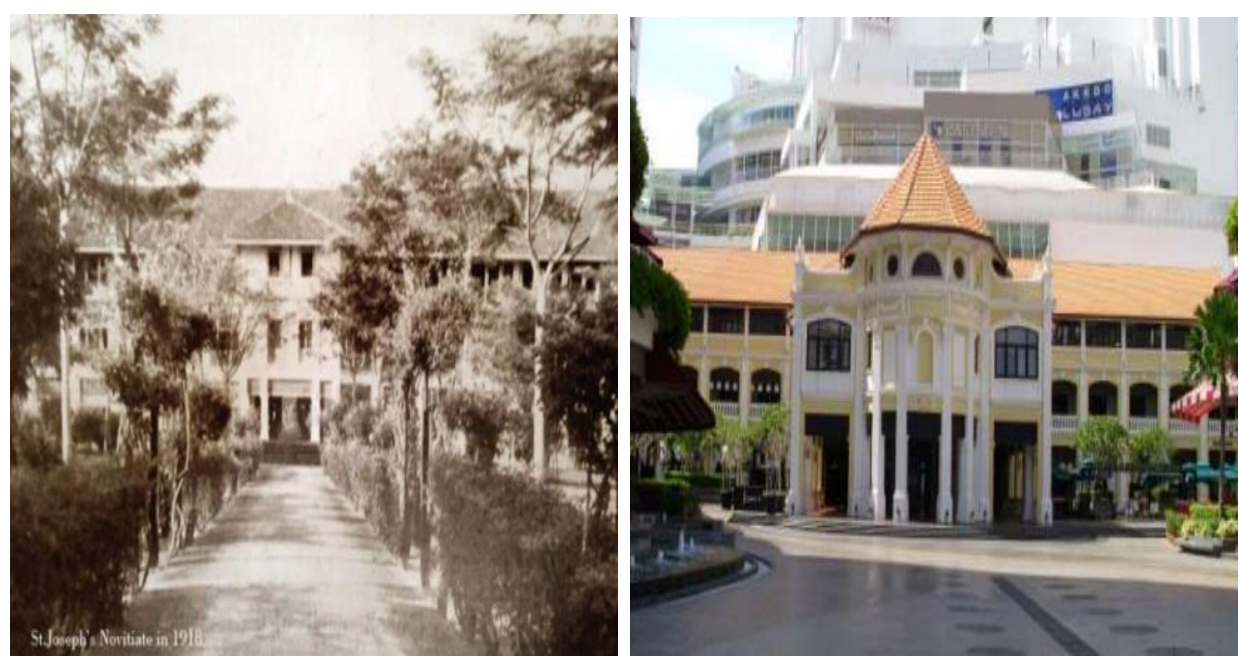

Figure 2: Image of the St. Joseph's Novitiate at 1918 and 2017

Source: www.hunzagroup.com, 2017

De La Salle, a Roman Catholic religious teaching order, pioneered mass education in Malaya as well as other places around the world. Novice clergymen came from the neighbouring countries of Singapore, Thailand, Myanmar, Hong Kong and Sri Lanka to complete their training in Penang. 1n 1918, the three-story St. Joseph's Novitiate was built facing the seafront along the North Beach of Penang Island, or Gurney Drive, as it is now known. St. Joseph's Novitiate was further extended in 1925 with the construction of a chapel attached to the middle section, creating a T-shape in the building's floor plan. This brought the total floor area to approximately 40,000 feet. The chapel, then known as St. Joseph's Chapel, was built under the supervision of Brother Cajetan L'Homaillfe of France, who was knowledgeable in the field of architecture. The beautiful stained glass windows were brought from Italy, and the altar and railings were made from imported marble. In the year of its completion, the exterior wall of the former chapel was carved-ANNO SANCTO MCMXXV, in Latin meaning 'holy year $1925^{\prime}$, which was when the extension was completed.

Later, in 1988, St. Joseph's Novitiate was leased to the International School of Penang (Uplands), who had relocated from St Xavier's Branch School on Kelawai Road, Penang. The international school occupied the premises until 2005, during which the space inside St Joseph's Novitiate had been converted into classrooms, laboratories, offices, dormitories and a library. The ground floor of St Joseph's Chapel was turned into a hall with a stage for performances, while the first floor of the chapel was converted into a library.

Gurney Paragon Mall was soft-launched and opened to the public on 23rd July 2013. The cost of restoration was approximately RM10 million, with RM3.5 million having been spent on stabilising the building's foundations. Gurney 
PLANNING MALAYSIA

Journal of the Malaysia Institute of Planners (2018)

Paragon Mall is a premier lifestyle shopping mall, home to an expansive dining area surrounded by well-known international retailers. At the centre of the mall stands the meticulously restored St. Joseph's Novitiate heritage building.

\section{METHODOLOGY}

Quantitative research is founded upon the philosophy of empiricism. According to Aliaga and Gunderson (1998), quantitative research is used to explain a phenomenon by way of numerical data that can be analysed mathematically using statistics. This numerical data can be presented in the form of percentages or other countable formats.

The questionnaire (Buss \& Perry, 1992; Krosnick \& Presser, 2010) based on data obtained from a literature review, was designed to assist with data collection. There were three objectives to this study, which revolved around trying to develop a better understanding of: (a) the history and background of Gurney Paragon Mall, (b) the conservation process for Gurney Paragon Mall, (c) and the impact of the restoration of the St. Joseph's Novitiate to Gurney Paragon Mall. Pursuant to these objectives, the questionnaire was divided into several sections, including a section for the collection of demographic data (Table 1).

Table 1: Summary of the variable and items in the questionnaires.

\begin{tabular}{llc}
\hline Section & Variable & Item \\
\hline Section A & Demography Profile & 6 \\
Section B & To identified History and Backgrounds & 3 \\
Section C & To understand the process in conservation & 3 \\
Section D & To determine the impact from the conservation & 4 \\
\hline Source: Authors 2017
\end{tabular}

Section A of the questionnaire survey is used to collect respondents' demographic data, including gender, age, race, country of origin, level of education and occupation. This information is useful in terms of understanding the sample and for determining its representativeness. Items in Section B aim to identify whether respondents have any prior knowledge about the history or background of Gurney Paragon Mall. This is necessary to identify their level of understanding with respect to heritage buildings. Section $\mathrm{C}$ records respondents understanding of the conservation process. This information can be useful for planning educational initiatives around conservation. Lastly, Sections D aims to determine the impact of the conservation of Gurney Paragon Mall. The objective of Section D is to understand how the respondents feel about the conservation process of Gurney Paragon Mall, especially with the new development having incorporated the heritage building.

Respondents for this study were identified via random sampling (Etikan, 2017; Kirk, 2011; Vitter, 1985). Sample size was determined based on the formula as described by Yamane (as cited in Hanafi, Umar, Razak, \& Rashid, 
Normah Abdul Latip, Norazmawati Md Sani@Abd Rahim, Syarmila Hany Haron, Rosniza Hamzah, Adaweia Nuur Abu Bakar, \& Mohd Umzarulazijo Umar

Visitors Perspectives Towards the Conservation of Heritage Building: The Case Study of Gurney Paragon Mall, Penang

2018). This formula was used to calculate the sample size for a $95 \%$ confidence level and precision $=0.05$. It was estimated that about 1,000 people will enter Gurney Paragon Mall. Based on the Yamane equation, this requires a sample size of approximately 286 respondents. However, due to the need for a homogenous population, the actual sample size should be smaller, thus improving the accuracy and depth of information provided by the respondents. Moreover, the cost of additional questionnaires would have exceeded the budget for this study. Time constrains were another reason to reduce the size of the sample. As the number of respondents increases, so too does the time required to administer the questionnaire survey and to clean-up and analyse the data. Consequently, the sample for this study was limited to less than 100 samples $(n<100)$.

\section{ANALYSIS AND FINDING}

One hundred (100) questionnaires were distributed to visitors of Gurney Paragon Mall. The researcher was responsible for the distribution of the questionnaires, which also provided an opportunity for the researcher to clarify any misunderstandings on the part of the respondents with regards to the questionnaire items. The researcher aimed to distribute approximately $80 \%$ of questionnaires; obviously the more responses received, the greater the validity of the data analysis (Table 2). Table 2 indicates the response rates at $82 \%$ from 100 respondent followed by $18 \%$ refused to answers due to private and confidential reasons.

Table 2: Response Rate

\begin{tabular}{lcc}
\hline & \multicolumn{2}{c}{ Visitor } \\
& Percentage (\%) & 100 \\
Total Distribute Questionnaire & 100 & 82 \\
Visitor Responded & 82 & 18 \\
Visitor Not Responded & 18 & \\
\hline
\end{tabular}

Source: Authors 2017

The data was analysed using SPSS Version 24. The question items were translated into simple terms to facilitate coding during the data analysis phase. The results shown in Table 3 in terms of demography profile namely gender, age, place origin and levels of education indicates a significant finding for gender equal at 50\% each. As for generations, the highest percentage with $73.2 \%$ dominantly by age group at 18-24-year-olds, followed by group age at 25-35 with $13.4 \%$ and the rest at 46 years old and above. Place of origin for the respondent indicates that $57.3 \%$ from outside Penang and the rest are locals. More than half of them possess a degree with $65.9 \%$ followed by diploma and certificates with $18.3 \%$ and the rest STPM and below. 
PLANNING MALAYSIA

Journal of the Malaysia Institute of Planners (2018)

Table 3: Demography Profile $(n=82)$

\begin{tabular}{|c|c|c|c|}
\hline \multicolumn{2}{|l|}{ Demography Profile } & Respondent & Percentage (\%) \\
\hline \multicolumn{4}{|l|}{ Gender } \\
\hline Male & Female & 41 & 50 \\
\hline Age & & 41 & 50 \\
\hline \multicolumn{4}{|l|}{$18-24$} \\
\hline $25-35$ & & 60 & 73.2 \\
\hline $36-45$ & & 11 & 13.4 \\
\hline $46-55$ & & 1 & 1.2 \\
\hline$>56$ & & 5 & 6.1 \\
\hline Place Origin & & 5 & 6.1 \\
\hline \multicolumn{4}{|l|}{ Penang } \\
\hline Outside Penang & & 35 & 42.7 \\
\hline Level of Education & & 47 & 57.3 \\
\hline \multicolumn{4}{|l|}{ PMR/SRP } \\
\hline SPM & & 1 & 1.2 \\
\hline STPM & & 6 & 7.3 \\
\hline Certificate/Diploma & & 4 & 4.9 \\
\hline Degree and above & & 15 & 18.3 \\
\hline Out of School & & 54 & 65.9 \\
\hline Occupation & & 2 & 2.4 \\
\hline \multicolumn{4}{|l|}{ Self-employed } \\
\hline Government & & 13 & 15.9 \\
\hline Private sector & & 5 & 6.1 \\
\hline Retiree & & 15 & 18.3 \\
\hline \multirow[t]{2}{*}{ Unemployed } & & 1 & 1.2 \\
\hline & & 48 & 58.5 \\
\hline
\end{tabular}

Table 4 indicates that the respondent visited Gurney Paragon with the primary goal for shopping at $59.8 \%$, followed by tour and travel with $22 \%$, and loungers at $12.2 \%$. The rest came for business deals and opportunities.

Table 4: Purpose to Gurney Paragon Mall ( $\mathrm{n}=82)$

\begin{tabular}{lcc}
\hline Purpose & Respondent & Percentage (\%) \\
\hline Tour/Travel & 18 & 22.0 \\
Shopping & 49 & 59.8 \\
Business & 5 & 6.1 \\
Loungers & 10 & 12.2 \\
\hline
\end{tabular}

Source: Author2017

Table 5 statistically revealed that $63 \%$ of the respondent had no idea that UNESCO recognises Gurney Paragon and $82 \%$ did not know that Gurney Paragon is also known as St. Joseph Novitiate. Meanwhile, 68\% were not aware that the building has undergone conservation process and 79\% did not know the 
Normah Abdul Latip, Norazmawati Md Sani@Abd Rahim, Syarmila Hany Haron, Rosniza Hamzah, Adaweia Nuur Abu Bakar, \& Mohd Umzarulazijo Umar

Visitors Perspectives Towards the Conservation of Heritage Building: The Case Study of Gurney Paragon Mall, Penang

process involved in the conservation of heritage sites. These indicates a reduced level of knowledge and awareness among the research subjects. This may require relevant stakeholders to introduce practical measures to ensure the sole purpose of conservation are well captured within the heart of visitors and travellers.

Table 5: Knowledge and Awareness $(n=82)$

\begin{tabular}{lcc}
\hline Aspects & Respondent & Percentage (\%) \\
\hline Know that Gurney Paragon Mall was & & \\
recognised by UNESCO & 30 & 37 \\
$\quad$ Yes & 52 & 63 \\
$\quad$ No & & \\
Know that Gurney Paragon Mall was & 15 & 18 \\
known as St. Joseph Novitiate & 67 & 82 \\
$\quad$ Yes & & \\
No & 26 & 32 \\
Know that Gurney Paragon Mall has & 66 & 68 \\
Undergoes Conservation Process & & \\
$\quad$ Yes & 17 & 21 \\
No & 65 & 79 \\
Know the Process Involved in & & \\
Conservation of Heritage Sites & \\
$\quad$ Yes & & \\
$\quad$ No & & \\
Source: Author 2017 &
\end{tabular}

Table 6 reveals that the mean values from five (5) aspect in visitors' perspectives (Ismail \& Nadarajah, 2016) namely cultural, structural, environmental, social and continuity aspects positively dictated at the range between 3.22-3.56. The average number significantly indicates that visitors' perspectives were in line with the study purpose.

Table 6: Visitor Perspective $(\mathrm{n}=82)$

\begin{tabular}{lc}
\hline Visitor Perspective & Mean Value \\
\hline Cultural Aspect & \\
$\quad$ Historical value & 3.40 \\
$\quad$ Artistic value & 3.46 \\
$\quad$ Authenticity of the building & 3.23 \\
Architectural Aspect & \\
$\quad$ Physical condition of the building & 3.51 \\
$\quad$ Space change & 3.22 \\
$\quad$ Materials and decorations of the Building & 3.39 \\
Environmental Aspect & \\
$\quad$ Site and surrounding condition & 3.34 \\
Scenic and contextual value & 3.33 \\
\hline
\end{tabular}


PLANNING MALAYSIA

Journal of the Malaysia Institute of Planners (2018)

\begin{tabular}{ll}
\hline Environmental quality of surroundings & 3.33 \\
Social Aspect & \\
Compatibility of newly building function & 3.24 \\
with existing public interest & 3.56 \\
Increase social value & 3.30 \\
Increase public awareness & 3.49 \\
Increase support and involvement & 3.50 \\
Continuity Aspect & 3.44 \\
Adequate protection and management system & 3.35 \\
Future change feasibility &
\end{tabular}

Source: Author 2017

The impacts of conservation can be described according to five perspectives or aspects, which are cultural, architectural, environmental, social and the continuity aspect. For the first aspect, which is the cultural aspect (Vecco, 2010), the perspectives of visitors to Gurney Paragon Mall tended to leaning towards high scores, indicating that visitors felt that the building still had historical and artistic value, and that its authenticity had been well preserved. This was largely due to the property developer having maintained the facade of the building in its original condition. One important pre-condition ahead of planning approval for the Gurney Paragon Mall project was that the developer undertake an evaluation of the feasibility of maintaining the facade of the building.

The second perspective concerns the architectural aspect (Akram \& Azizi, 2017; Ilozor, 2008; Pukhkal, 2015). Visitors were receptive to the architectural design of the building, agreeing that it was still in good condition and that the design features of the original heritage building were still apparent in the general architecture of the more modern Gurney Paragon Mall. The professionals charged with the responsibility of overseeing the preservation of St. Joseph's Novitiate similarly agreed that the building's architectural aspect had been maintained in good condition. Their main concern, however, was the facade. As long as the facade of the building is well maintained, then the rest of the building should be similarly maintained. The upper floor of the building has also been conserved and left largely unchanged. Nonetheless, the transition from novitiate to shopping mall can still be a confronting transformation for many people. However, it is hoped that this development will provide an opportunity to educate the public on an innovated conceptual approach to the preservation of heritage buildings while including them in the daily work-living space of a building.

The third aspect concerns the environment. This aspect (Kamaruzzaman, Lou, Zainon, Mohamed Zaid, \& Wong, 2016; Rodrigues \& Freire, 2017; Watt, 2001) relies on the perspectives of visitors and what they think of the surrounding environment. Although St. Joseph's Novitiate is now somewhat hidden from 
Normah Abdul Latip, Norazmawati Md Sani@Abd Rahim, Syarmila Hany Haron, Rosniza Hamzah, Adaweia Nuur Abu Bakar, \& Mohd Umzarulazijo Umar

Visitors Perspectives Towards the Conservation of Heritage Building: The Case Study of Gurney Paragon Mall, Penang

view due to the new development, the overall condition of the surrounding environment is good. However, while Gurney Paragon Mall does not reflect much the heritage value of St. Joseph's Novitiate, the building does at least preserve the value of St. Joseph's Novitiate's heritage.

The social aspect (ICOMOS, 2010; Yung, Zhang, \& Chan, 2017) is the fourth perspective in determining the impact of conservation to Gurney Paragon Mall. This aspect again concerns visitors and whether they think that the conservation of St. Joseph's Novitiate will increase the social awareness and involvement of people in the conservation and preservation of heritage buildings. It is assumed that by converting St. Joseph's Novitiate into a shopping mall people will have the opportunity to experience a heritage building before they are lost to history.

The final perspective is the continuity aspect. Continuity here implies that both visitors and respondents think that the conservation of Gurney Paragon Mall will not create any issues or problems in the future. One important requirement levied by the municipal council was that the developer undertake to preserve the building's facade. Had the developer ignored this requirement to preserve the facade of the building, planning permission would not have been granted by the local authority.

\section{CONCLUDING REMARK}

The first objective of this study has been achieved, which is to identify the history and background of Gurney Paragon Mall. St. Joseph's Novitiate was purchased by the developer before being restored and incorporated into the architecture of a new shopping mall. The second objective has also been achieved - to determine the impact of conservation of Gurney Paragon Mall. The impact of conservation is gauged according to five aspects, which concern cultural, architectural, environmental, social, and continuity impacts. Based on the findings, respondents were generally satisfied, with $90 \%$ supporting the conservation of Gurney Paragon Mall. Nonetheless, while there were some minor issues regarding the conservation work, respondents generally satisfied so long as the conservation efforts do not harm the heritage building either now or in the future. 


\section{ACKNOWLEDGEMENT}

We gratefully acknowledge Universiti Sains Malaysia and Ministry of Education Malaysia for funding this project through Fundamental Research Grant Scheme, FRGS, (Grant No: 203/PPBGN/6711404).

\section{REFERENCES}

Abdul Rashid, R., \& Ahmad, A. G. (2011). Overview of maintenance approaches of historical buildings in Kuala Lumpur - A current practice. Procedia Engineering, 20, 425-434.

Ahmad, A. G. (2006). The framework of historical building conservation. Sejarah@Malaysia, 1(1), 50-56.

Akram, Z., \& Azizi, B. (2017). The sustainable architectural values of eclectic style shophouses case study: Sun Yat Sen Museum Penang, Malaysia. Panggung, 27(2), 108-116.

Aliaga, M., \& Gunderson, B. (1998). Interactive statistics. Upper Saddle River, NJ: Pearson.

Azmin, A. K., Kassim, M. H., Abdullah, F., \& Sanusi, A. N. Z. (2017). Architectural heritage restoration of Rumah Datuk Setia via mobile augmented reality restoration. Planning Malaysia, 15(1), 139-50.

Buss, A. H., \& Perry, M. (1992). The aggression questionnaire. Journal of Personality and Social Psychology, 63(3), 452-459.

Department of Statistics Malaysia (2018). Department of Statistics Malaysia Official Portal. [online] Available at https://www.dosm.gov.my/v1/index.php?r=column/cone\&menu_id=SEFobmo 1N212cXc5TFILVTVxWUFXZz09 [Accessed 8 Aug. 2018].

Etikan, I. (2017). Sampling and sampling methods. Biometrics \& Biostatistics International Journal, 5(6), 00149

Harun, S. N., Ahmad, A. G., \& Badarulzaman, N. (2004, August). Conservation and archaeology of Fort Cornwallis, Penang, Malaysia. First International Conference on Science and Technology in Archaeology and Conservation, August 12-17, 2002, Jordan.

Hanafi, M. H., Umar, M. U., Razak, A. A., \& Rashid, Z. Z. A. (2018). Essential entities towards developing an adaptive reuse model for organization management in conservation of heritage buildings in Malaysia. Environment-Behaviour Proceedings Journal, 3(7), 265-276.

ICOMOS. (2010). Changing world, changing views of heritage: Heritage and social change. Proceedings of the ICOMOS scientific symposium. Paris: ICOMOS International Secretariat.

Ilozor, B. D. (2008). Architectural and building features disparity and preservation of structural and fabrics integrity. Journal of Engineering, Design and Technology, 6(1), 33-47.

Ismail, W. H. W., \& Nadarajah, J. R. (2016). Young visitors in the city: Their perceptions of heritage buildings. Procedia - Social and Behavioral Sciences, 234, 470-477.

Jenkins, G., \& King, V. T. (2003). Heritage and development in a Malaysian City: George Town under threat? Indonesia and the Malay World, 31(89), 44-57.

Kamaruzzaman, S. N., Lou, E. C. W., Zainon, N., Mohamed Zaid, N. S., \& Wong, P. F. 
Normah Abdul Latip, Norazmawati Md Sani@Abd Rahim, Syarmila Hany Haron, Rosniza Hamzah, Adaweia Nuur Abu Bakar, \& Mohd Umzarulazijo Umar

Visitors Perspectives Towards the Conservation of Heritage Building: The Case Study of Gurney Paragon Mall, Penang

(2016). Environmental assessment schemes for non-domestic building refurbishment in the Malaysian context. Ecological Indicators, 69, 548-558.

Kirk R.E. (2011) Simple Random Sample. In Lovric M. (Eds), International encyclopedia of statistical science. Springer, Berlin, Heidelberg. https://doi.org/10.1007/9783-642-04898-2_518

Krosnick, J. A., \& Presser, S. (2010). Question and questionnaire design. In P. V. Marsden, \& J. D. Wright, (Eds.), Handbook of survey research (pp. 263-314). Bingley, UK: Emerald.

Lee, L. M., Lim, Y. M., \& Nor’Aini, Y. (2008). Strategies for urban conservation: A case example of George Town, Penang. Habitat International, 32(3), 293-304.

Leng, K. S., Badarulzaman, N., Samat, N., Rohayah, S., \& Dawood, S. (2014). Capitalising on urban cultural resources for creative city development: A conceptual review and the way forward for Malaysia's George Town. Malaysian Journal of Society and Space, 10(5), 20-29.

Pukhkal, V. (2015). Saving the architectural appearance of the historical buildings due to heat insulation of their external walls. Procedia Engineering, 117, 891-899.

Rodrigues, C., \& Freire, F. (2017). Building retrofit addressing occupancy: An integrated cost and environmental life-cycle analysis. Energy and Buildings, 140, 388-398.

Vecco, M. (2010). A definition of cultural heritage: From the tangible to the intangible. Journal of Cultural Heritage, 11(3), 321-324.

Vitter, J. S. (1985). Random sampling with a reservoir. ACM Transactions on Mathematical Software, 11(1), 37-57.

Watt, D. (2001). Investigating the effects of site and environmental conditions on a historic building and its contents. Structural Survey, 19(1), 46-57.

Yung, E. H. K., Zhang, Q., \& Chan, E. H. W. (2017). Underlying social factors for evaluating heritage conservation in urban renewal districts. Habitat International, 66, 135-148.

Zawawi, N. A. W. A., \& Abdullah, A. (2011). Evaluating stakeholders' preferences: Reconciling heritage and sustainability in Kuala Lumpur traditional areas. Planning Malaysia, 9, 37-50

Received: $1^{\text {st }}$ June 2018. Accepted: $1^{\text {st }}$ December 2018 